\title{
A survey: perioperative diabetes medications and glucose control-time to re-examine management?
}

\author{
Russell Brown, MDMC, PhD, FRCPC (D) - Urooj Siddiqui, MD • \\ James Paul, MD, MSc, FRCPC
}

Received: 14 December 2018/Revised: 24 January 2019/Accepted: 30 January 2019/Published online: 6 February 2019

(C) Canadian Anesthesiologists' Society 2019

\section{To the Editor,}

Anesthesia and surgery induce a number of metabolic derangements particularly in those with type- 2 diabetes (T2D) ${ }^{1-3}$ Hyperglycemia (blood glucose $>11 \mathrm{mmol} / \mathrm{L}$ ) is associated with risks including increased surgical site infection, thromboembolism, and myocardial infarction. ${ }^{1,2}$ Lowering glucose by even $1 \mathrm{mmol} \cdot \mathrm{L}^{-1}$ is reported to reduce surgical site infections. ${ }^{4}$ Canadian population trends suggest we are increasingly likely to care for hyperglycemic patients perioperatively; accordingly, best management practices should be investigated and developed.

Following institutional ethical approval, we surveyed 2,415 practicing members of the Canadian Anesthesiologists Society with a six-question survey designed to assess practice patterns regarding perioperative diabetes management (eTable, full survey available as Electronic Supplementary Material). The survey was initially emailed on 22 June 2018, with two reminders sent to non-responders, and the survey closed six weeks later. Overall, we received $223(9.2 \%)$ responses.

Our survey revealed that half $(112 ; 50.2 \%)$ of respondents work in a department with a formal policy

Electronic supplementary material The online version of this article (https://doi.org/10.1007/s12630-019-01311-0) contains supplementary material, which is available to authorized users.

R. Brown, MDMC, PhD, FRCPC (₫) · J. Paul, MD, MSc, FRCPC

Department of Anesthesia, McMaster University, Hamilton, ON, Canada

e-mail: Russell.brown@medportal.ca

U. Siddiqui, MD

Department of Anesthesiology, University of Saskatchewan,

Saskatoon, SK, Canada regarding the perioperative management of diabetes medications. Interestingly, 221 (97\%) respondents hold all oral glucose-lowering medications on the day of surgery (Table). ${ }^{1,2}$ The primary decision on how to manage these medications appears largely driven by historical teaching $(104 ; 46.6 \%)$ and clinical experience $(52 ; 23.3 \%)$, with only two $(<1 \%)$ having noted research-based evidence as their primary guide. Similarly, only 12 (5.4\%) of respondents would consider cancelling a case if blood glucose was $>15 \mathrm{mmol} / \mathrm{L}$; the majority would only cancel if blood glucose was $>20 \mathrm{mmol} \cdot \mathrm{L}^{-1}(109 ; 48.9 \%)$, and some $(61 ; 27.4 \%)$ would not cancel even if blood glucose was $>30 \mathrm{mmol}$.

This survey raises several important issues regarding current perioperative management of patients with T2D. Discrepancies between current evidence, guidelines, and actual practice suggests implementing any new interventions into routine practice might remain an important barrier. Additionally, advice on perioperative medication use is often managed using medical directives executed by preadmission nurses, and simply holding all medications makes it easier to maintain consistency, which can avoid unnecessary cancellations. Indeed, certain medications should be withheld, such as insulin secretagogues to avoid inducing hypoglycemia, and sodium glucose-cotransporter 2 (SGLT-2) inhibitors to avoid normoglycemic diabetic ketoacidosis (Table). ${ }^{1,2,5}$ Several other glucose-lowering medications (i.e., thiazolidinediones, dipeptidyl peptidase-4 [DPP-4] inhibitors, glucagon-like peptide-1 analogues, and metformin) appear safe to continue perioperatively and may even help to manage glucose following surgery. ${ }^{1,2}$ Although this strategy has garnered support by some anesthesia societies, ${ }^{1,2}$ they remain to be tested in clinical 
Table Perioperative management of oral glucose-lowering medications

\begin{tabular}{|c|c|c|c|c|c|}
\hline $\begin{array}{l}\text { Approach to perioperative use } \\
\text { of glucose-lowering } \\
\text { medications }\end{array}$ & $n$ & $\begin{array}{l}\text { Hold on } \\
\text { day of } \\
\text { surgery } \\
n(\%)\end{array}$ & $\begin{array}{l}\text { Continue usual } \\
\text { dose on day of } \\
\text { surgery } \\
n(\%)\end{array}$ & $\begin{array}{l}\text { Continue reduced } \\
\text { dose on day of } \\
\text { surgery } \\
n(\%)\end{array}$ & Recommendations by Duggan et al. $2017^{1}$ \\
\hline $\begin{array}{l}\text { a. Biguanides } \\
\text { (e.g., metformin) }\end{array}$ & 224 & $220(98.2)$ & $3(1.3)$ & $1(0.5)$ & $\begin{array}{l}\text { Take on day of surgery UNLESS anticipate } \\
\text { reduced oral intake, large fluid shifts, or use of } \\
\text { contrast dyes }\end{array}$ \\
\hline $\begin{array}{l}\text { b. Secretegogues } \\
\text { (e.g., repaglinide, gliclazide) }\end{array}$ & 223 & $219(98.2)$ & $4(1.8)$ & 0 & Hold on day of OR \\
\hline $\begin{array}{l}\text { c. SGLT-2 inhibitors } \\
\text { (e.g., dapagliflozin, } \\
\text { canagliflozin) }\end{array}$ & 221 & $217(98.2)$ & $4(1.8)$ & 0 & Should be held day before and on day of OR \\
\hline $\begin{array}{l}\text { d. DPP-4 inhibitors } \\
\text { (e.g., sitagliptin) }\end{array}$ & 223 & $219(98.2)$ & $4(1.8)$ & 0 & Should be continued on day of OR \\
\hline $\begin{array}{l}\text { e. GLP-1 analogues } \\
\text { (e.g., exenatidine) }\end{array}$ & 220 & $214(97.3)$ & $6(2.7)$ & 0 & No formal recommendations made \\
\hline $\begin{array}{l}\text { f. Thiazolidinediones } \\
\text { (e.g., pioglitazone) }\end{array}$ & 221 & $216(97.7)$ & $4(1.8)$ & $1(0.5)$ & $\begin{array}{l}\text { Take on day of surgery UNLESS anticipate } \\
\text { reduced oral intake or large fluid shifts }\end{array}$ \\
\hline
\end{tabular}

DPP-4 = dipeptidyl peptidase-4; GLP-1 = glucagon-like peptide-1; OR = operating room; SGLT-2 = sodium glucose-cotransporter 2

trials, and may have contributed to their limited adoption into routine practice.

A wide variation in practice exists with regards to what glucose values may trigger case cancellation. Although no formal guidelines exist regarding when blood glucose values should trigger delaying elective surgery, random preoperative blood glucose values $>12 \mathrm{mmol} \cdot \mathrm{L}^{-1}$ correlate with a two-fold increase in all-cause, and a four-fold increase in cardiovascular-related mortality and thus may represent a reasonable target. ${ }^{1,3}$ This questions whether reducing blood glucose to $<12 \mathrm{mmol} \cdot \mathrm{L}^{-1}$ actually offers any benefit, and how best to accomplish this. Although insulin can be used, variable degrees of insulin resistance that occur following surgery make dosing challenging, and risks the development of profound hypoglycemia. ${ }^{2,4}$ Notably, patients with T2D treated with glucose-lowering medications prior to surgery appear to have improved outcomes relative to those who remain untreated, and their perioperative continuation may offer some benefit to maintain more physiologic regulation. ${ }^{3}$ Perhaps some universal guidelines may help facilitate the optimization and management of hyperglycemic surgical patients.

As the incidence of T2D continues to increase, anesthesiologists will have to remain dynamic and regularly re-evaluate the management of hyperglycemic patients in an attempt to continuously improve care within resources that are at times limited.
Conflicts of interest None declared.

Editorial responsibility This submission was handled by Dr. Hilary P. Grocott, Editor-in-Chief, Canadian Journal of Anesthesia.

\section{References}

1. Duggan EW, Carlson K, Umpierrez GE. Perioperative hyperglycemia management: an update. Anesthesiology 2017; 126: 547-60.

2. Membership of the Working Party; Barker P, Creasey PE, Dhatarya $K$, et al. Peri-operative management of the surgical patient with diabetes 2015: Association of Anaesthetists of Great Britain and Ireland. Anaesthesia 2015; 70: 1427-40.

3. Noordzij PG, Boersma E, Schreiner $F$, et al. Increased preoperative glucose levels are associated with perioperative mortality in patients undergoing noncardiac, nonvascular surgery. Eur J Endocrinol 2007; 156: 137-42.

4. Umpierrez GE, Smiley D, Jacobs $S$, et al. Randomized study of basal-bolus insulin therapy in the inpatient management of patients with type 2 diabetes undergoing general surgery (RABBIT 2 surgery). Diabetes Care 2011; 34: 256-61.

5. Peacock SC, Lovshin JA. Sodium-glucose cotransporter-2 inhibitors (SGLT-2i) in the perioperative setting. Can J Anesth 2018; 65: 143-7.

Publisher's Note Springer Nature remains neutral with regard to jurisdictional claims in published maps and institutional affiliations. 